\title{
Cultural Heritage Tourism Preservation: Kota Tua Jakarta Indonesia Versus Old Town Central Hong Kong
}

\author{
Rahmi Setiawati* \\ Tourism Studies, Vocational Education Program, Universitas Indonesia \\ *Email: rahmisetyawati@yahoo.com
}

\begin{abstract}
The purpose of this study was to compare the cultural heritage tourism preservation in two heritage sites: Kota Tua Jakarta in Indonesia and Old Town Central in Hong Kong. This was done to produce cross-national comparisons in similarities, differences, and how the sites are preserved. The study focused on preservation systems and efforts, such as funding, management, ownership, stakeholder involvement, spatial distribution within the sites, community concerns of tourism and signage, and the physical settings of the sites. This explorative research used a qualitative approach to obtain more accurate results within the context of comparisons between the two cultural heritage sites. In this study, we conducted field and online observation techniques, documentation, notes, and literature studies. To obtain the primary data, onsite observation sessions were conducted directly in the Old Town Central Hong Kong and Kota Tua Jakarta areas, and in-depth interviews and photo documentation were done as well. Moreover, the secondary data collection for the Old Town of Jakarta was completed through an online literature study in the form of news, trip advisors, and travel notes. This paper raises suggestions to settle some ways of preserving historical heritage by making a comparative discussion on the differences in legislation, administration, and government support in the two countries of Hong Kong and Indonesia that can be applied to any kind of cultural heritage tourism site performance for sustainability purposes.
\end{abstract}

Keywords: preservation, cultural heritage sites, tourism, Kota Tua Jakarta, Old Town Central

\section{$1 \quad$ Introduction}

The study of cultural tourism has been discussed in literature (McKercher, 2015; Boccella \& Salerno, 2016; Hani et al., 2012; Herliana, 2015, Silberberg, 1995). However, there has been great discussion among researchers attempting to distinguish between cultural tourism and heritage tourism. The discussion brings up several definitions of cultural tourism. As stated by Christou (2005), the term "cultural tourism," which is used interchangeably with "heritage tourism" or "ethnic tourism," usually offers tourists the attraction of cultural traditions, places, and values, such as religious practice, folklore traditions, and social customs of certain communities or ethnicities. This study supports the notion that cultural tourism is as a form of tourism that relies on a destination's cultural heritage assets and forms them into products that can be consumed by tourists (McKercher \& Cros, 2005, pp. 211-212). Referring to this definition, cultural tourism involves four elements: 1) tourism; 2) the use of cultural assets; 3 ) the consumption of experiences and products; and 4) the tourist. Cultural tourism involves the traveler learning about the history of a place and the foreign community heritage or way of life. In addition, it includes the involvement of any activity or something that can offer an infinite experience (Zakaria, Salleh, \& Rashid, 2014). Christou (2005) and Csapo (2012) argue that heritage tourism can provide a scan or past nostalgic experience or reality. This study aims to explore and examine the following questions: 1) What are the similarities and differences between Kota Tua Jakarta and Old Town Central Hong Kong?; and 2) How are these two sites preserved for sustainability purposes?

\section{Study Areas}

This study was conducted in two sites, namely Kota Tua Jakarta Indonesia and Old Town Central Hongkong (Figure 1). The site selection was due to the high potential for a cultural heritage tourism opportunity and the great extent of tourist visits to the places. 


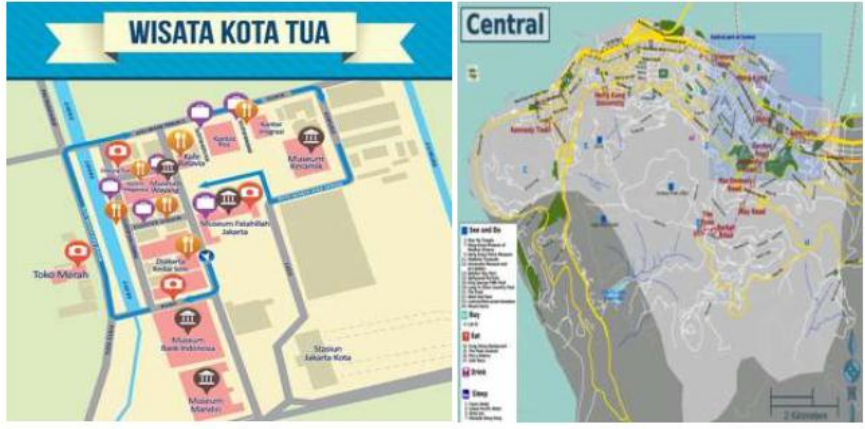

Figure: 1: Study area (https://www.google.com, accessed 17 August 2017)

\section{Literature Review}

This study is based on literature reviews on several aspects of heritage and cultural tourism as follows:

\section{Cultural Heritage Tourism}

For many developing countries, tourism is the only way to participate in the global economy and develop their own economies (Jelinčić, in Urošević, 2012). Tourism brings people from other areas to the community. This means that the community has attractions that others are willing to travel to see. Some tourist destinations, such as waterparks, have a generic quality that does not say anything special about the community where they are located. However, cultural heritage attractions have a nature that is very specific to a community's past or present characteristics. Decisions about how to develop and manage cultural heritage attractions help the community and present it to the outside world. Participation in these decisions helps build the community and bolster pride among its residents. In addition, cultural heritage tourism is the coordinated and mutually supportive application of cultural, heritage, and tourist resources for the improvement of the overall quality of community life (McNulty and Koff, 2014). Travelers who are interested in cultural heritage tourism visit or take part in any of the following: 1) historical attractions, monuments, or landmarks; 2) museums, art galleries, or theaters; 3) festivals, concerts, or performances; and 4) culturally significant neighborhoods or communities. Tourists who are interested in cultural heritage generally want to learn something about the beliefs and practices and the struggles and successes that have shaped the shared identity of a people. Some of these tourists may share a degree of ancestry with the people whose history they are interested in (McNulty and Koff, 2014, p. 7). Specifically, Cros and McKercher (2015) elaborate the classification of cultural tourism product categories, as presented in Table 1.

Table 1: Classification of cultural tourism product categories

\begin{tabular}{lll}
\hline$N_{0}$ & \multicolumn{1}{c}{ Product Category } & \multicolumn{1}{c}{ Example } \\
\hline 1 & Built non touristic & Archaeological, sites, ruins \\
\hline 2 & Touristic purpose: built or modified & Theme parks, museum, cultural centre \\
\hline 3 & Economic & $\begin{array}{l}\text { Industrial heritage attraction based on primary } \\
\text { production (mining) }\end{array}$ \\
\hline 4 & Transport & Canals, maritime structure \\
\hline 5 & Cultural landscape & Historic town, seaside resort \\
\hline 6 & Creative industries & Art performance \\
\hline 7 & Religious & Religious sites, sacred sites \\
\hline 8 & Diaspora ethnic & Diaspora urban ethnic, festivals and event \\
\hline 9 & Extant ethnic & Minority cultures, handicraft \\
\hline 10 & Intangible Heritage & Tradition. Custom, folklore, oral tradition \\
\hline 11 & Dark & War sites, battle fields \\
\hline 12 & Natural heritage (mixed values) & Conservation areas, botanic, garden \\
\hline
\end{tabular}

Source: du Cros and Bob McKercher, 2015

Table 1 explains that there are roughly 12 classifications of cultural tourism products. Since each product has different characteristics, each requires different preservation management. Kota Tua Jakarta meets the 
classification numbers 2, 3, 5, 6, 9, and 10. Kota Tua Jakarta meets the classification number 2 because its tangible product is an area consisting of heritage buildings, museums, parks, traditional attractions, and traditional foods and drinks. It also meets classification number 3 for economic benefit purposes as it functions as a place where some heritage attractions are held, especially on the weekend, and as a cultural landscape as well (classification number 5).

Kota Tua Jakarta is clearly presented as a historic town. The legacy of the colonial Dutch is built as a European small town, as is seen from the style of the buildings along the street and around the museum. On the weekend, people from other parts of the city may come and sell their products to the tourists. They can also perform some types of attractions, such as art performances or small shows. They can sell handicrafts as well. They can also perform some traditional attractions, such as traditional dances or children's plays or choirs, with governmental agreement. These activities meet classification numbers 6, 9, and 10. While in Old Town Central Hong Kong, the site meets classification number 5. Old Town Central is a historical town where the ancient British colony came and began building in Hong Kong.

Furthermore, cultural heritage is the record of a people manifest in the tangible (cultural relics, handicrafts, monuments, historic towns, and villages) and intangible (literature, theater, music, folk customs) heritage of their culture (McKercher, 2015). Cultural heritage assets can be either tangible or intangible entities. Within the context of architectural heritage, these may include tangible structures, such as buildings, historic areas, special heritage districts, or cultural landscapes. Cultural heritage assets may include intangible assets relating to the traditional lifestyle of a society. This can include daily activities, customs, beliefs, rituals, ways of life, and music (Chu and Uebergang, 2007). It is also apparently stated that tangible cultural heritage includes all assets that have some physical embodiment of cultural values, such as heritage cities, historic towns, buildings, archaeological sites, cultural landscapes, cultural objects, collections, and museums (UNESCO WHC et al., 2013; ICOM, 2014b).

Other scholars have noted the evolving framework of cultural heritage management (Table 2). This helps elaborate cultural heritage management with five phases, each consisting of some key features explaining the qualification of each phase's features.

Based on Table 2, Kota Tua Jakarta accomplishes the phase of inventory as it is running well by the government as well as initial legislation. This site also needs the third phase (increased professionalism), which involves non-governmental organizations (NGOs) and the social community. The next step involves stakeholder consultation from many sectors to develop the site, such as academicians, businesses, the government, the community, and media. In the review phase, Kota Tua Jakarta already gives a new understanding of responsibilities for tourists and communities. It also raises the recognition of other users. However, the rest of the five features in this phase have not yet been accomplished. While in Old Town Central Hong Kong, it seems like they only meet the first phase. However, the rest of the phases have not been implemented yet, referring to the concept presented in Table 1 that Old Town Central only applies to one category of cultural landscape.

\section{Preservation in Heritage Cultural Tourism}

Major cities in developing countries face similar issues related to high development pressure, a lack of concern for cultural heritage, and little or no public participation in the decision-making process of urban development and conservation (Kong and Yeoh, 1994; Steinberg, 1996). In Hong Kong, however, the largest challenge to heritage conservation undoubtedly lies in the limitation of usable land, the current land policy, and a growing population. This creates pressure to continuously redevelop existing urban fabrics to accommodate new structures. Development has always been given primary consideration because it is seen as a major means of promoting economic growth. As a result, many of the city's historic buildings have already surrendered to the prevailing commercial imperative. In the face of such pressures, successfully undertaking conservation will require a design vision for the city that articulates the role of heritage conservation. To be successful, such a vision must explicitly recognize the social importance of conservation. It must also establish a framework that allows for an inclusive, flexible, and ongoing identification of areas of heritage value. In addition, it requires a means of prioritizing competing interests and concerns in the process of achieving this vision. Cultural heritage plays an important role in forming a self-identity and sharing a collective history. Referring to this, heritage preservation is becoming a vital part of maintaining and enhancing the social capital of a city and quality of life. Preservation can be defined as the action taken to maintain the fabric of a place in its existing state and retard deterioration (Chu and Uebergang, 2007). One of the purposes of preservation is to care for assets for the enjoyment of present and future generations. To be successful, cultural heritage tourism projects must attract tourists, preserve heritage spaces and places, and engage community residents. Any one of these elements can get out of balance with the others and prevent a successful outcome. Additionally, preservation and conservation are common terms referring to the safeguarding and protection of cultural heritage. Usually, preservation has a narrower meaning: all actions taken to maintain an object in its existing condition, minimize the rate of change, slow down further deterioration, and/or prevent damage (Community Museums Program, 2009). Conservation 
encompasses preservation and involves the careful management of assets for the use of future generations. Heritage preservation as a public discourse and public agendum was a project of modernity, and its birth coincided with the birth of modern nation-states (Ip, 2010; Yen, 2005; Hagen, 2006; Boyer, 1994). Heritage preservation is a modern product, but that does not mean that what is now known as heritage preservation did not exist in the pre-modern period. There were practices to deal with and protect heritage, but these were not systematic policies practiced in the public domain.

\section{Methodology}

This explorative research used a qualitative approach to obtain deeper and more accurate results within the context of comparisons between two cultural heritage sites. In this study, we used field and online observation techniques, including photo documentation, taking notes, and literature studies. To obtain the primary data, field observation was conducted directly in Kota Tua Jakarta Indonesia and Old Town Central Hong Kong, as well as in-depth interviews with tour leaders and tourists visiting the area. Documentation was made, and photos were taken as well. Secondary data collection was done through an online literature study in the form of news, trip advisors, and travel notes. In addition, data and information were classified and analyzed based on McKercher's theory on possible relationships between tourism and cultural heritage assets, as well as the five types of cultural tourists.

\section{Results and Discussion}

\subsection{Results from Observation}

Research was conducted using the observation technique (August 2017), and Table 3 presents the result of onsite observation conducted in Old Town Central.

Table3: Results of on-site observation

\begin{tabular}{llll}
\hline$N_{0}$ & \multicolumn{1}{c}{ Aspects } & \multicolumn{1}{c}{ Kota Tua Jakarta } & \multicolumn{1}{c}{ Old Town Central HK } \\
\hline 1 & Ownership & Government intervention & Private \\
\hline 2 & Attraction Management & Managed with purposes & Managed without purposes \\
\hline 3 & Legacy and Legality & Protectd by government law & $\begin{array}{l}\text { Without protection by } \\
\text { government law }\end{array}$ \\
\hline 4 & Zoning & Zoning for tourism purposes & Zoneless for tourism \\
\hline 5 & Entry fee & With entry fee & No entry fee \\
\hline 6 & Signage & With signage & No signage \\
\hline 7 & Concerns for tourism & High & Low \\
\hline 8 & Settlement & Without residents & With resident \\
\hline Source: Observation, August 2017 &
\end{tabular}

In general, Table 3 explains that Old Town Central in Hong Kong has a number of additional factors that pose obstacles to the practice of heritage preservation. These including a lack of understanding of heritage preservation and its potential lack of long-term preservation policy, fragmented priorities, inadequate coordination of the government and residents living within the sites, a lack of mechanisms to compensate developers and property owners, and a lack of public involvement in decision making. Recent efforts by the government to improve the protection of Hong Kong's cultural heritage include the establishment of the CHC in November 2000. The CHC is a nonexecutive body whose role is to advise the government on policy and funding priorities for culture and the arts (pers.com, Tour Guide, August 11, 2017). For detailed analysis, Old Town Central Hong Kong and Kota Tua Jakarta Indonesia are described as follows:

Ownership: The pattern of ownership in Kota Tua Jakarta is under the government's control. This is indicated by the existence of regional regulations in the preservation of the Jakarta Old Town area. Meanwhile, based on the interviews and observation in Old Town Central, the ownership is held individually. A lack of a governmental role is impacting the pattern of maintenance of old buildings in Hong Kong. The owners tend to sell their own buildings for sale and earn financially.

Attraction Management: In Kota Tua Jakarta, the attraction is already managed by the government by involving the local community. In addition to some interesting sites, the community has a chance to be actively involved, such as by selling souvenirs, bicycle rentals, and guiding city tours. The sites are designed for tourism 
purposes. While in Old Town Central Hong Kong, the sites still need more attention in terms of management. Visitors could not see the tour program comprehensively. The sites are not designed for tourism purposes.

Legacy and Legality: As a cultural legacy, referring to the classification in Table 1, Old Town Central Hong Kong did not meet many categories. The site only meets one cultural landscape category as a historical town. However, actually, as a legacy, Old Town Central is not protected by the government's law in term of preservation. It has not been treated as a legacy, especially as a cultural heritage legacy. This situation can easily be seen from the tangible or physical evidence, whereas in Old Town Central, the tourists would find a mixture of old and modern buildings all together side by side. So it is difficult to see Old Town Central as a heritage legacy of an ancient cultural site if the tourists do not know the history of the site being the place where the colonial British came for the very first time in Hong Kong centuries ago. While in Kota Tua Jakarta, the government plays an important role in protecting and preserving the legacy site through a preservation law. Everything is established as a heritage legacy there.

Zoning: In Kota Tua Jakarta, the zoning area is already fixed, and the layout of the area is firm. According to the government's law and local government decree, the layout of Kota Tua Jakarta has been assigned and is completed with signage. The tourists can choose which part of Kota Tua Jakarta they go to, be it the museum, park, food area, merchandize area, and so on. While in Old Town Central Hong Kong, the tourists would not find differences among any part in the site. This happened because the site consists of individual properties. So the owner is allowed and has the right to do whatever they want on their properties without any zoning at all.

Entry Fee: In Kota Tua Jakarta, the entry fee is applied in some areas, such as at the museums (Wayang Puppet Museum, Art \& Ceramic Museum, Bank Indonesia Museum, Maritime Museum). For other areas, there is no entry fee applied for open areas, such as in the park or in the food area. For the entry to Syahbandar Tower, there is no entry fee, so tourists can choose and adjust their preferences based on their situation. In Old Town Central, as the site is an open area, and the neighborhood is private property, there is no entry fee applied.

Signage: Kota Tua Jakarta has been completed with good signage. Tourists can easily find the direction to the area they want to visit. While in Old Town Central, there is no signage applied, except as the name of some spots such as Hollywood Road Park.

Community Concern for Tourism: Community concern leads to the involvement of all stakeholders participating in tourism. This kind of approach has become an integral part of contemporary sustainable tourism development. This can minimize the negative impacts and maximize the positive impacts of tourism. The positive concern can only be achieved through mutualism symbiosis between all parties. For Kota Tua Jakarta, the locals get direct social and economic benefits from tourism activities within the sites, whereas for Old Town Central Hong Kong, it is the opposite. The local community is driven by business alone.

Settlement: Local settlement in heritage areas mostly disturbs the preservation process because many domestic activities potentially bring many physical threats to the sites. In Kota Tua Jakarta, local settlement in the area is prohibited due to its historic colonial backgrounds as well as the awareness of cultural preservation by the government and community. While in Old Town Central Hong Kong, the area has been set up for public settlement or residency since the colonial era.

Table 4 presents the onsite observation results, which were analyzed according to the possible relationship between tourism and cultural heritage assets (McKercher \& Cros, 2012) 
Table 4: Review Summary of teory applied to the two sites

\begin{tabular}{|c|c|c|c|}
\hline \multirow[b]{2}{*}{ RELATIONSHIP } & \multirow[b]{2}{*}{ DESCRIPTION } & \multicolumn{2}{|c|}{ SITES } \\
\hline & & $\begin{array}{l}\text { Old Town Central } \\
\text { Hongkong }\end{array}$ & $\begin{array}{c}\text { Kota Tua } \\
\text { Jakarta }\end{array}$ \\
\hline \multirow{2}{*}{ Full Coorporation } & $\begin{array}{l}\text { True partnership for mutual } \\
\text { benefit of both }\end{array}$ & 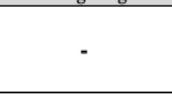 & - \\
\hline & $\begin{array}{l}\text { Likely imposed or heavily } \\
\text { managed }\end{array}$ & - & - \\
\hline \multirow{3}{*}{ Working Relation } & $\begin{array}{l}\text { Realization of common needs and } \\
\text { interest }\end{array}$ & - & $\sqrt{ }$ \\
\hline & Begin dialogue & - & $\sqrt{ }$ \\
\hline & $\begin{array}{l}\text { Work to ensure that both interest } \\
\text { are satisfied }\end{array}$ & & $\sqrt{ }$ \\
\hline \multirow{3}{*}{$\begin{array}{l}\text { Peaceful } \\
\text { Co-Existence }\end{array}$} & Sharing the same resources & $\sqrt{ }$ & - \\
\hline & $\begin{array}{l}\text { Derive mutual benefit from ist } \\
\text { use, but still largerly separate and } \\
\text { independent }\end{array}$ & $\sqrt{ }$ & - \\
\hline & $\begin{array}{l}\text { Some dialogue, but little } \\
\text { coorperation or recognition of } \\
\text { need to cooperate }\end{array}$ & $\sqrt{ }$ & - \\
\hline \multirow{3}{*}{$\begin{array}{l}\text { Paralel Existance / } \\
\text { Blissfull } \\
\text { Ignorance }\end{array}$} & Separate and independent & $\sqrt{ }$ & - \\
\hline & Little or no contact & $\sqrt{ }$ & - \\
\hline & Out of sight, out of mind & - & - \\
\hline \multirow{4}{*}{ Mild Annoyance } & $\begin{array}{l}\text { Goal interference attributable to } \\
\text { one stakeholder }\end{array}$ & - & - \\
\hline & Lessened satisfaction & $\sqrt{ }$ & - \\
\hline & $\begin{array}{l}\text { One stakeholder exerts adverse } \\
\text { effects, but little real conflict }\end{array}$ & $\cdot$ & - \\
\hline & $\begin{array}{l}\text { Lack of understanding between } \\
\text { stakeholders }\end{array}$ & $=$ & - \\
\hline \multirow[b]{2}{*}{ Nascent Conflict } & $\begin{array}{l}\text { Problem defying easy solution } \\
\text { emerge }\end{array}$ & - & - \\
\hline & $\begin{array}{l}\text { Changing power relationship with } \\
\text { emergence of one dominant } \\
\text { stakeholders whoose need are } \\
\text { detrimental tot he other } \\
\text { established stakeholder }\end{array}$ & - & - \\
\hline Full Conflict & Open conflicts & - & - \\
\hline
\end{tabular}

Source: On-site observation (2017) and McKercher \& Cros (2012).

\subsection{Results from Documentation and Self-Report}

The findings and results from self-report summary pictures taken to capture the authentic scenes and the atmosphere in the environment around the sites are presented as follows. 


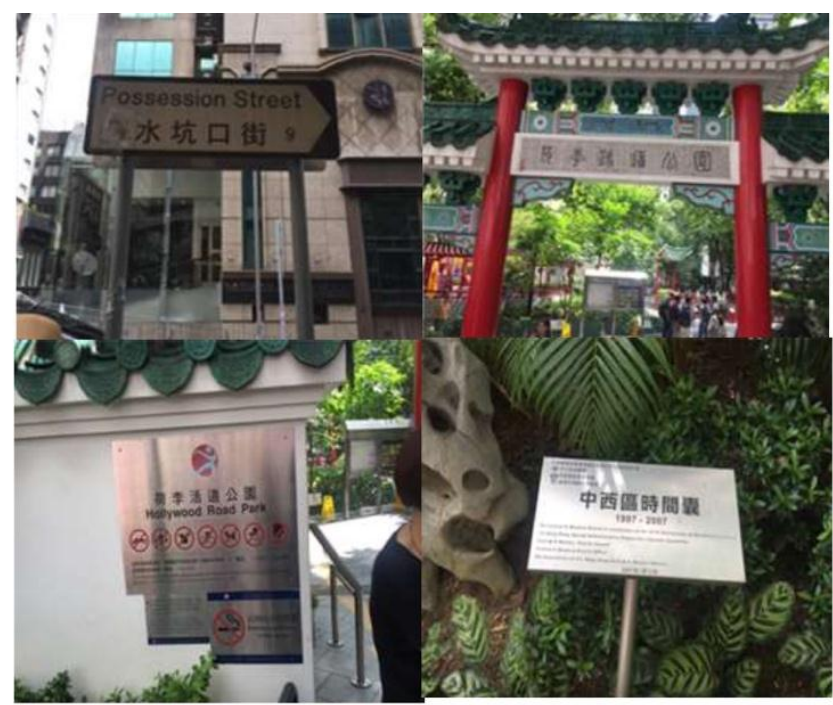

Figure 2: Authenticity value to preserve of the OTC, Hong Kong (On-site observation, 2017)

Figure 2 describes Hollywood Road Park and the artifact of the Association of the Hong Kong Central and Western District. This explains that the site's environment is basically the same from year to year, except for the buildings. The owners of buildings are free to change the facade or even the building due to no governmental law on heritage preservation. It shows the first place where the ancient British colony came to Hong Kong. This is the reason the site is called "Central," which refers to the central British colony from their first step in Hong Kong. Meanwhile, the name "Hollywood" is nothing to do with the city of Hollywood in Los Angeles, California, US. It is the same name as the one in the United States, but this Hollywood in Old Town came from the ancient situation where this area was a forest of Holly trees/plants (pers.com., August 11, 2017).

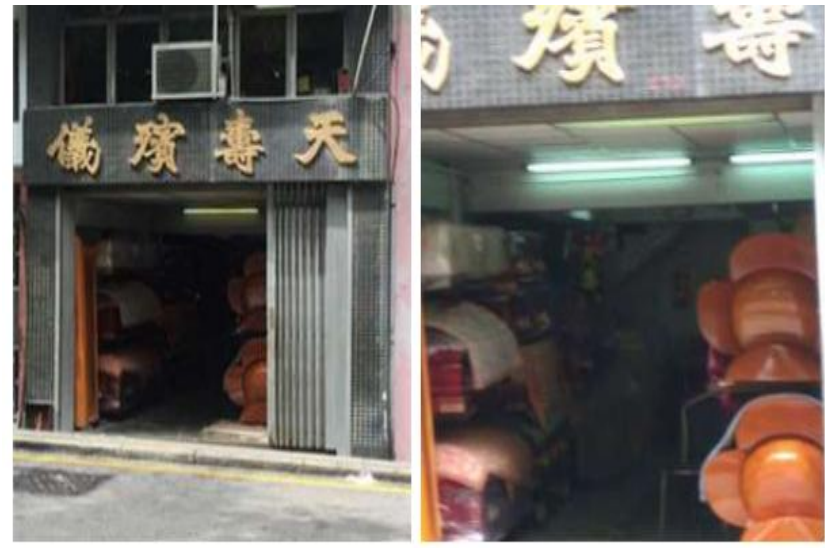

Figure 3: Coffins Shop (On-site observation, 2017)

Figure 3 shows the harmony of living together with traditional and Western colony cultures. On the left side in the picture are some Western coffins, and on the right side are traditional Chinese coffins.

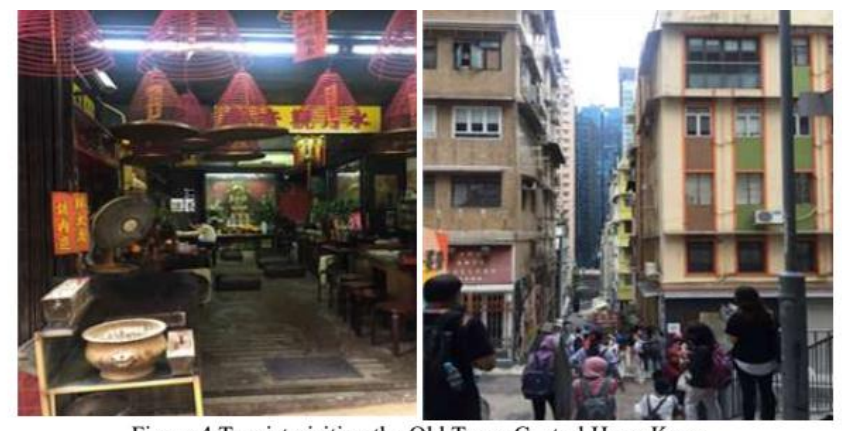

Figure 4 Tourist visiting the Old Town Central Hong Kong

(On-site observation, August2017) 
Figure 4 explains how the traditional Chinese design, colonial living style (represented by the red brick building), and modern buildings can be set side by side in Old Town Central.

\subsection{Results from In-Depth Interviews}

This research also used in-depth interviews with the tour leader and tourists visiting the areas. This is used to explain several first-hand opinions and ideas about the site.

\section{Site management}

In terms of site management, Old Town Central Hong Kong is not preserved under the government law, as explained below:

The Old Town Central in Hong Kong is not protected by the government's law in order to preserve the cultural heritage of original neighborhood. So everyone who own a buildingwhether it is an apartment or business place like cafe, gallery, art shop, etc.-is free to change or even demolish their property as they like. This actually is a threat of the existing heritage in Old Town due the next generation might be never know how their ancestor life looks is. (Tour leader, August 2017)

\section{Tourist Impressions}

First-time travelers were asked about their first impression of Old Town Central Hong Kong, which varied in some negative comments, as stated below:

The Old Town Hong Kong seem put the objects as they like (not by purpose), nothing special and too ordinary. To me, old central tour is just a gimmick of Hong Kong. Fabricated experience of old Hong Kong. The lack of heritage sense, explained by: After visited OTCHK, I still can found some traditional and old buildings like temple, tea shop, or shop selling materials for ritual in the temple, but they also have new modern buildings there side by side with the old buildings. The modern building, even more than the old buildings. So I did not feel like in an old town at all. It did not meet my expectation, not too impressed totally different from the expectation. (Tourist, August 2017)

These comments contrast with the following:

After visited OTCHK, I was impressed with the topography of the land, which is very unique because it is located on a hilly land...attractive and very potential to be presented as tourist attraction. (Tourist, August 2017)

\section{Promotion and Website Design}

From an online marketing perspective, the visitor give opinions on the promotion materials.

The Old Town Central Hong Kong benefits from its colorful and rich website content. Their websites gives many information about events, shops, and things to do for the visitors. While the Kota Tua Jakarta don't have their own website. The lack of information about the history, insight, and things to do give negative impacts, it can be seen in the visitors' negative comments about the site. (Tourist, August 2017)

The five types of cultural tourists, according to McKercher and Cros (2012), include the purposeful cultural tourist, the sightseeing cultural tourist, the serendipitous cultural tourist, the casual cultural tourist, and the incidental cultural tourist.

\section{Conclusion}

This research concludes that the two cultural heritage sites, Kota Tua Jakarta in Indonesia and Old Town Central in Hong Kong, are mostly different in terms of preservation efforts, site management, tourism concerns, and government support. The two sites have great cultural heritage potential values to be presented as tourism attractions within the area. However, Kota Tua Jakarta gets more attention and intervention from the government 
to intentionally preserve regional assets for cultural heritage preservation and tourism purposes. Kota Tua is protected and preserved under governmental law, whereas this is not applied to Old Town Central Hong Kong. Old Town Central in Hong Kong is not purposely managed as a touristic site and/or preservation area. In addition, the local communities in Old Town Central Hong Kong are living within the site with their daily activities and even with no concerns about cultural heritage tourism values, whereas in the Kota Tua Jakarta, it is prohibited under governmental law, and no residents are allowed to live within the site. However, from sustainable perspectives, this study does not claim that Kota Tua Jakarta is more successful than Old Town Central Hong Kong in terms of cultural heritage preservation due to the fact that preservation and heritage values more likely appear and are physically performed in the sense of a touristic atmosphere to be subjectively determined.

\section{References}

Boccella, N., \& Salerno, N. (2016). Creative economy, cultural industries and local development. Procedia - Social and Behavioral Sciences, 223, 291-296.

Brida, J. G., Meleddu, M., \& Paulina, M. (2013). The economic impacts of cultural tourism. In M. Smith and G. Richards (Eds.), The Routledge handbook of cultural tourism (pp. 110-115). New York: Routledge Books.

Christou, E. (2005). Heritage and cultural tourism: A marketing-focused approach. International Cultural Tourism: Management, Implications and Cases, 3-16.

Chu, C., \& Uebergang, K. (2007). Saving Hong Kong's cultural heritage. Civic Exchange.

Cros, H., \& McKercher, B. (2015). Cultural tourism (2nd ed.). Routledge.

Dwyer, L., Forsyth, P., \& Dwyer, W. (2010). Tourism economics and policy. In C. Cooper, C. M. Hall, and D. J. Timothy (Eds.), Aspects of tourism texts, Bristol, Buffalo, Toronto: Channel View Publication.

Foscarini, F., Oliver, G., Ilerbaig, J., \& Krumrei, K. Preservation cultures, developing a framework for a culturally sensitive digital preservation agenda.

Galí-Espelt, N. (2012). Identifying cultural tourism: A theoretical methodological proposal. Journal of Heritage Tourism, $7(1), 45-48$

Hani, U., Azzadina, I., Sianipar, C. P. M., Huda, E., Setyagung, E. H., \& Ishii, T. (2012). Preserving cultural heritage through creative industry: A lesson from Saung Angklung Udjo. International Conference on Small and Medium Enterprises Development with a Theme Innovation and Sustainability in SME Development (ICSMED 2012).

Herliana, E. T. (2015). Preserving Javanese culture through retail activities in Pasar Beringharjo, Yogyakarta, Procedia Social and Behavioral Sciences, 184, 206-213.

Hong Kong Tourism (2017). Old Town Central-self guided walks in the heart of Hongkong.

Jucan, C. N., \& Sabina, M. (2013). Travel and tourism as a driver of economic recovery. Procedia Economics and Finance, $6,81-88$

Lenzi, I. (2004). Museums of Southeast Asia. Singapore: Archipelago Press.

Marilena, A. (2016). Intangible heritage and the museum, new perspectives on cultural tourism. New York: Routledge.

McKercher, B. \& Cros, H. (2005) Cultural heritage and visiting attractions. In D. Buhalis and C. Costa (Eds.), Tourism business frontiers: Consumers, products and industry (pp. 211-219). Butterworth-Heinemann.

McKercher, B., \& Cros, H. (2012). The partnership between tourism and cultural heritage management. USA: Routledge.

Ministry of Education and Culture Directorate General of Culture (2015). The principles of cultural heritage preservation: Protection, development and utilization. IORA Workshop on Cultural Tourism Padang, 17-19.

Silberberg., T. (1995). Cultural tourism and business opportunities for museums and heritage sites. Tourism Management, $16(5), 361-365$.

UNESCO (2003). UNESCO Convention for the safeguarding of the intangible cultural heritage. Retrieved from http://www.unesco.org/culture/ich/index.php?lg=en\&pg=00006

Urošević, N. (2012). Cultural identity and cultural tourism. Singidium Journal of Applied Science, 9(1), 67-76.

Zakaria, A. Z., Salleh, I. H., \& Rashid, M. S. A. (2014). Identity of Malay garden design to be promoted as the cultural tourism product in Malaysia. Procedia-Social and Behavioral Sciences, 153, 298-307. 